\title{
FORMAÇÃO DE AUDIODESCRITORES CONSULTORES: INCLUSÃO E ACESSIBILIDADE DE PONTA A PONTA
}

\author{
Manoela da Silva* \\ Alessandra Barros**
}

\section{RESUMO}

A audiodescrição (AD) é uma modalidade de tradução que torna acessível a pessoas cegas ou com baixa visão o conteúdo imagético de produtos visuais ou audiovisuais. Contudo, para que essa acessibilidade seja, de fato, garantida é preciso que a qualidade dessas ADs seja assegurada. A presença do audiodescritor consultor, profissional com deficiência visual responsável por conceder feedback especializado, muito pode contribuir nesse sentido. Entretanto, isso só será possível se os consultores tiverem a capacitação e o perfil necessários para o exercício de sua função. Neste estudo, um desdobramento de pesquisa anterior publicada sob o título de Audiodescritor consultor: competências necessárias ao profissional não vidente, ${ }^{1}$ aliamos as conclusões da referida pesquisa a nossa experiência pessoal em cursos de capacitação no intuito de delinear diretrizes que venham nortear propostas de qualificação de pessoas com deficiência visual para o trabalho com AD. Preconizamos que consultores sejam formados em conjunto com roteiristas e narradores em cursos que aliem teoria e prática e tenham ênfase no trabalho colaborativo. Desse modo, a inclusão e a acessibilidade não estarão restritas apenas ao consumo, mas permearão todo o processo, ou seja, da formação dos profissionais à produção e fruição dos produtos audiodescritos.

Palavras-chave: Deficiência visual. Audiodescrição. Formação de audiodescritores consultores.

\section{ABSTRACT}

\section{THE TRAINING OF AUDIO DESCRIPTION CONSULTANTS: INCLUSION AND ACCESSIBILITY FROM A TO Z}

Audio description (AD) is a form of translation that makes visual or audiovisual products accessible to blind or visually impaired people. However, for such accessibility to be truly guaranteed, the quality of the descriptions must be ensured. The presence of an audio description consultant, the visually impaired professional responsible for providing specialized feedback in the area, can greatly contribute in this regard. Yet, this will only be possible if consultants have the profile and the qualification required to carry out their duties. In this study, an extension of a previous research published under

1 Ver Silva (2016).

* Mestre em Letras e Linguística pela Universidade Federal da Bahia (UFBA). Professora adjunta do curso de Letras da UFBA. Coordena o grupo de pesquisa Tradução, Mídia e Audiodescrição (TRAMAD/UFBA). E-mail: penteacher2@yahoo.com.br

** Pós-doutora em Políticas Sociais pela Universidade de Brasília (UnB). Doutora em Ciências Sociais pela Universidade Federal da Bahia (UFBA). Professora Associada 1 na Faculdade de Educação e no Programa de Pós-Graduação em Educação da UFBA. E-mail: alssb@ufba.br 
the title of "Audiodescritor consultor: competências necessárias ao profissional não vidente", we combine the conclusions of the aforementioned research with our personal experience as a trainer in order to outline guidelines for proposals of qualification of visually impaired people to work in the field of $\mathrm{AD}$. We recommend that consultants be formed along with writers and narrators in courses that combine theory and practice and emphasize collaborative work. This way, inclusion and accessibility will not be restricted to consumption, but permeate the whole process, that is, from the training of professionals to the production and enjoyment of audio described products.

Keywords: Visual impairment. Audio description. The training of audio description consultants.

\section{RESUMEN}

\section{FORMACIÓN DE CONSULTORES EN AUDIODESCRIPCIÓN: INCLUSIÓN Y ACCESIBILIDAD DE PRINCIPIO A FIN}

La audiodescripción (AD) es una modalidad de traducción que hace accesibles a personas ciegas o con baja visión productos visuales o audiovisuales. Sin embargo, para que esta accesibilidad sea, de hecho, garantizada es necesario que la calidad de esas descripciones sea asegurada. La presencia del consultor en audiodescripción, profesional con discapacidad visual responsable de conceder feedback especializado, mucho puede contribuir en ese sentido. Sin embargo, esto sólo será posible si los consultores tienen el perfil y la capacitación necesarios para el ejercicio de su función. En este estudio, un desdoblamiento de investigación anterior que se publicó bajo el título de "Audiodescritor consultor: competências necessárias ao profissional não vidente", complementamos las conclusiones de dicha investigación con nuestra experiencia personal en cursos de capacitación con el fin de delinear directrices que vengan a orientar propuestas de calificación de personas con discapacidad visual para el trabajo con AD. Preconizamos que los consultores sean formados en conjunto con guionistas y narradores en cursos que alian teoría y práctica y tengan énfasis en el trabajo colaborativo. De este modo, la inclusión y la accesibilidad no estarán restringidas sólo al consumo, sino que permearán todo el proceso, es decir, desde la formación de los profesionales a la producción y el disfrute de los productos audiodescriptos.

Palabras clave: Discapacidad visual. Audiodescripción. Formación de consultores en audiodescripción.

\section{INTRODUÇÃO}

A audiodescrição (AD) é uma modalidade de tradução intersemiótica que converte informações visuais em texto verbal, ou seja, imagens em palavras. Ela pode ser usada tanto para a tradução de material audiovisual (filmes de cinema, programas de TV, peças de teatro, espetáculos de dança, apresentações circenses etc.), como de imagens estáticas (pinturas, esculturas, quadrinhos, charges, mapas, gráficos etc.).

O público primário da $\mathrm{AD}$ é composto por pessoas com deficiência visual para as quais o recurso garante inúmeros benefícios: aquisição de conhecimentos acerca da cultura vidente (linguagem corporal, estilos de roupa etc.); experiência mais prazerosa e educativa com materiais visuais/audiovisuais; sentimento de maior cidadania, inclusão e independência; ${ }^{2}$ e maior segurança para conversar

2 Em geral, quando não existe oferta de $\mathrm{AD}$, muitas pessoas com deficiência visual acabam necessitando de um acompanhante para que possam desfrutar de experiências como uma exibição de fotografias. Uma das vantagens da $\mathrm{AD}$ reside, justamente, no fato de proporcionar a seus usuários maior autonomia, desobrigando familiares ou amigos da tarefa de descrever e reduzindo 
com pessoas videntes acerca dos programas e eventos dos quais participam (PACKER, 1995 apud PACKER, 1996; SCHMEIDLER; KIRCHNER, 2001).

A importância da AD para o público com deficiência visual é facilmente reconhecida. Entretanto, pesquisas também têm apontado a utilidade do recurso para pessoas com outras necessidades específicas como autistas (FELLOWES, 2012), pessoas com deficiência intelectual (CARNEIRO, 2015) e até mesmo surdos (RIBEIRO; LIMA, 2012). Além disso, o seu uso parece trazer vantagens inclusive para videntes ao enriquecer o vocabulário de crianças pequenas quando associada à contação de histórias (SNYDER, 2008), como uma alternativa quando alguma eventualidade venha a impedir que se possa dirigir o olhar à tela onde um filme ou programa de TV esteja sendo exibido, como um recurso para estrangeiros aprendendo uma nova língua, ou como suporte extra para idosos (RAI; GREENING; PETRÉ, 2010).

Como a $\mathrm{AD}$ é, em geral, utilizada como um recurso de tecnologia assistiva, o princípio básico que norteia o processo de tradução é tornar acessível, por meio de palavras, informações-chaves transmitidas de modo essencialmente visual. Ao traduzir, o audiodescritor cria um roteiro que servirá de apoio àquelas pessoas que têm o seu acesso às imagens impedido ou dificultado. $O$ roteiro de $A D$ é, então, verbalizado através de voz humana ou via softwares computacionais. No caso de materiais audiovisuais, o roteiro aproveita-se das pausas dos diálogos ou momentos de silêncio para inserir descrições do cenário, figurino, personagens etc., bem como informações sobre mudanças espaço-temporais, por exemplo. No caso de imagens estáticas, os roteiros contêm informações como autoria, estilo, dimensão, disposição, cor, textura etc., assim como a verbalização de qualquer texto escrito que acompanhe as imagens (balões em histórias em quadrinhos ou charges, por exemplo).

a necessidade da presença de acompanhantes. Isto também evita situações constrangedoras, pois, ao descrever as imagens durante uma sessão de cinema ou um espetáculo teatral, os acompanhantes irão fatalmente incomodar os demais espectadores. Como o que se preconiza com a acessibilidade e a inclusão é a convivência harmoniosa entre os diferentes, a mera presença da $\mathrm{AD}$ assegura que videntes e pessoas com deficiência visual possam ocupar um mesmo espaço físico sem que nenhum deles tenha seu direto ao lazer e à informação cerceados.
Qualquer que seja o material traduzido ou a modalidade de AD, a mecânica de trabalho é semelhante. Em geral, trabalha-se em equipe e mais de um tipo de profissional está envolvido na tradução: o roteirista, o consultor e o narrador. O audiodescritor roteirista, ou a equipe de roteiristas, é responsável pela criação do roteiro de AD. O audiodescritor consultor, que é necessariamente uma pessoa com deficiência visual, é responsável por averiguar a adequação do roteiro a seu público primário em termos de suas necessidades e preferências. Por fim, o audiodescritor narrador é responsável por gravar em estúdio ou ler ao vivo o roteiro finalizado. ${ }^{3}$

A revisão especializada conduzida pelo audiodescritor consultor tem se tornado uma prática relativamente comum no Brasil. O raio de ação dos consultores, entretanto, pode diferir bastante a depender de cada prestador de serviço. Na maioria dos casos, o consultor atua como revisor de roteiros previamente elaborados por audiodescritores videntes. Há casos mais raros, contudo, nos quais a participação do consultor é mais efetiva e ele desenvolve os roteiros em parceria com seus pares videntes. Seja qual for o modelo adotado, a importância do consultor é amplamente reconhecida e sua participação no processo vista como garantia de qualidade.

No entanto, se o que se quer é realmente qualidade, é necessário que a função de consultor seja exercida por profissionais, já que a atividade da audiodescrição é um ofício reconhecido desde 2013, quando passou a integrar a Classificação Brasileira de Ocupações (CBO). Assim como nem todo vidente pode ser roteirista, nem toda pessoa com deficiência visual pode atuar como consultor. São necessários um perfil específico e o devido treinamento.

3 É importante frisar que um mesmo profissional pode assumir mais de uma das funções descritas, ou seja, um roteirista, a depender da qualidade de sua voz e competência para narração, pode ler ou gravar o próprio roteiro. Além disso, em casos excepcionais, uma pessoa com deficiência visual também pode atuar como roteirista ou narrador. Audiodescritores com baixa visão, por exemplo, podem escrever roteiros com o auxílio de recursos de tecnologia assistiva que ampliem imagens ou aumentem o contraste entre figura e fundo. Além disso, se um roteiro estiver em Braille, um cego pode atuar como narrador desde que tenha sido treinado e tenha voz adequada para tal fim. 
Neste artigo, portanto, nos propomos a discutir a importância do papel do consultor e de uma formação sólida e em conjunto com os demais profissionais da AD para que a inclusão e a acessibilidade não estejam restritas apenas ao consumo, mas permeiem todo o processo, ou seja, da formação dos audiodescritores à produção e fruição dos produtos audiodescritos.

\section{A IMPORTÂNCIA DO FEEDBACK ESPECIALIZADO}

$\mathrm{A} \mathrm{AD}$, assim como a tradução para crianças, é uma modalidade tradutória assimétrica, isto é, ela é produzida por pessoas que não pertencem ao público-alvo. No caso da tradução para o público infantil, são os adultos (pais, professores, editores, escritores, tradutores etc.) que escrevem, traduzem, publicam, criticam, adotam e compram as obras para as crianças. Suas decisões estão baseadas na sua imagem pessoal do que seja uma criança e aquilo que acreditam melhor atender à formação, compreensão e preferências do público infantil (O'SULLIVAN, 2006a; 2006b). No caso da AD, são videntes (na figura dos roteiristas) que traduzem obras para pessoas com deficiência visual, obras essas originalmente produzidas por videntes e para videntes. Suas decisões também estão baseadas naquilo que acreditam melhor atender as necessidades e preferências de pessoas cegas ou com baixa visão. Entretanto, mesmo que sejam utilizadas estratégias como o uso de vendas de olhos, a experiência do "não ver" não pode ser reproduzida e, portanto, o feedback especializado garantido pela participação dos audiodescritores consultores é uma ferramenta fundamental para minimizar um dos possíveis efeitos negativos da assimetria: a adesão a normas inadequadas.

Ao longo da história, muitos voluntários, pessoas sem qualquer formação em $\mathrm{AD}$, assumiram o papel de "audiodescritores", descrevendo informalmente tudo aquilo que podia interessar a seus familiares ou amigos com deficiência visual. Além disso, mesmo quando o recurso foi alçado ao patamar de uma atividade técnica e especializada, os pioneiros na área, aqueles roteiristas profissionais responsáveis por difundir o recurso e escrever as primeiras normas de $\mathrm{AD}$, não eram tradutores. Como consequência, muitos dos parâmetros pre- sentes nos primeiros guias a normatizar a prática da audiodescrição de imagens acabaram por se revelar problemáticos.

Como os primeiros manuais não foram escritos por tradutores, era comum, por exemplo, a preconização da neutralidade e da objetividade como se fosse possível evitar qualquer tipo de interpretação por parte do audiodescritor. ${ }^{4}$ Também era comum a recomendação de uma narração neutra, independentemente do tipo de material a ser descrito. Outro problema apontado pela maioria dos estudiosos e pesquisadores da área é o fato de que essas normas “[...] geralmente carecem de argumentos sólidos para embasar as regras que propõem" (BITTNER, 2012, p. 58, tradução nossa). Vercauteren (2012) discorre sobre o problema nos seguintes termos:

Primeiro, os guias nunca mencionam por que você tem que descrever os elementos que eles citam, isto é, eles são bastante intuitivos e não têm qualquer fundamentação teórica. Além disso, eles são ou muito gerais, indicando o que deve ser descrito em um único parágrafo, como a norma espanhola UNE 153020, ou muito específicos, concentrando-se em alguns elementos particulares, como cor ou etnia, mas não em outros. ${ }^{6}$ (VERCAUTEREN, 2012, p. 211, grifo do autor, tradução nossa). ${ }^{7}$

Além de todas essas falhas, há ainda o agravante de que foram pessoas que enxergam aquelas que

4 A ideia de que o ato tradutório seja meramente a transferência de significados fixos e estáveis foi desconstruída ao se reconhecer no tradutor um leitor. Uma vez que o próprio texto de partida, seja ele verbal ou não, apresenta diversos significados em potencial, ou seja, permite diversas leituras a depender do contexto em que está inserido e de quem o lê, não existe um único original, mas várias possíveis leituras e, consequentemente, várias possíveis traduções de um mesmo texto.

5 " $[\ldots]$ they usually lack a sound argument for the rules they put forward."

6 "First, the guidelines never mention why you have to describe the elements they mention, i.e., they are rather intuitive and lack any form of theoretical grounding. In addition, they are either very general, stating what has to be described in one single paragraph, such as the Spanish UNE 153020 Standard, or very specific, focusing on some particular elements such as colour or ethnicity, but not on others."

7 O guia elaborado como resultado do projeto Audio Description: Lifelong Access for the Blind (ADLAB) é, claramente, uma exceção. O próprio Vercauteren, inclusive, participou do projeto. No entanto, o referido guia só foi publicado em 2014 e é pouquíssimo conhecido no Brasil. Em geral, pelo menos até a publicação da norma brasileira em 2016, as normas internacionais que embasavam a prática brasileira eram a americana, a inglesa, a espanhola e a alemã. Todas elas se enquadram nesse perfil criticado pelos pesquisadores em $\mathrm{AD}$. 
estavam à frente das iniciativas que geraram as primeiras normas em $\mathrm{AD}$; o que levou à criação de parâmetros de caráter visocêntrico.

O termo "visocentrismo", também grafado como "visuocentrismo", refere-se a um modo de conhecer e agir no mundo centrado no sentido da visão e que iguala o "ver" à normalidade, tornando-o o padrão pelo qual a sociedade se organiza:

Ainda que a existência humana não seja privilégio de quem enxerga, são as pessoas que podem ver (videntes/normovisuais) as responsáveis pela organização do mundo em todas as suas estruturas - políticas, econômicas, científicas, sociais e culturais [...] [E assim] organizadas para e pelas pessoas que podem ver, estas estruturas afetam diretamente os cegos e as pessoas com baixa visão. (MATTOSO, 2012, p. 63).

No caso das primeiras normas em AD, a pessoa com deficiência visual não é vista como uma pessoa completa em si mesma e com direito a uma interpretação própria e igualmente aceitável dos materiais traduzidos, mas ela é compreendida a partir e em comparação com o ideal normovisual. É por isto que podemos encontrar no texto de alguns dos primeiros guias afirmações como:

A audiodescrição é um serviço de apoio à comunicação que consiste em um conjunto de técnicas e habilidades aplicadas com o objetivo de compensar a carência de captação de informação visual contida em qualquer tipo de mensagem, fornecendo uma informação sonora adequada que a traduz ou explica, de maneira que o possível receptor com deficiência visual perceba a referida mensagem como um todo harmônico e da forma mais parecida com a qual a percebe uma pessoa que vê. ${ }^{8}$ (ASOCIACIÓN ESPAÑOLA DE NORMALIZACIÓN Y CERTIFICACIÓN, 2005, grifo nosso, tradução nossa).

A ideia é a de que a experiência de videntes e cegos deva ou possa ser igualada e de que esse deva ser o objetivo final da AD. Essa linha de pensamento é o que justifica a existência de regras que tomam a experiência dos videntes com materiais visuais/

8 "La audiodescripción es un servicio de apoyo a la comunicación que consiste en el conjunto de técnicas y habilidades aplicadas con objetivo de compensar la carencia de captación de la parte visual contenida en cualquier tipo de mensaje, suministrando una adecuada información sonora que la traduce o explica, de manera que el posible receptor discapacitado visual perciba dicho mensaje como un todo armónico y de la forma más parecida a como lo percibe una persona que ve." audiovisuais como base para a tomada de decisões no momento da roteirização. Em termos práticos, é o visocentrismo em $\mathrm{AD}$ que justifica a máxima de que não se deve fornecer nenhum conteúdo extra à pessoa com deficiência visual e a de que o roteiro só deve conter informações a que as pessoas que enxergam têm acesso através do próprio texto fonte; não se pode esquecer, no entanto, do fato de que quem vê já carrega consigo todo um conjunto de informações da cultura vidente que é utilizado como aporte para interpretar aquilo a que assistem. É também o visocentrismo em AD que está na base de problemas como, por exemplo:

a) A decisão de nomear personagens somente após terem seus nomes revelados na trama, ou seja, no exato momento em que os videntes obteriam essa informação. Tal situação pode acarretar a criação de sentenças longas e de difícil compreensão como: "A mulher de camisa azul segura a mão do menino de boné vermelho e caminha em direção ao homem de terno";

b) A opção de se descrever gestos e expressões faciais de um modo "objetivo", mesmo quando se sabe que muitas pessoas com deficiência visual podem simplesmente não compreender o que é dito, ou seja, dar preferência a "A bibliotecária ergue o dedo indicador em riste e o posiciona em frente aos lábios" em vez de "A bibliotecária faz sinal de silêncio colocando o dedo indicador em riste à frente dos lábios". Ou "Ele arregala os olhos e abre a boca. Suas pupilas estão dilatadas" em vez de "Ele toma um susto";

c) A preferência por uma narração neutra e a diretriz de que $\mathrm{AD}$ não pode brilhar tanto quanto a trilha sonora original, pois ela não é parte integrante do texto fonte e isto deve estar claro para os espectadores que dela fazem uso; tal afirmação persiste mesmo quando se sabe da importância do sentido da audição para pessoas que não enxergam ${ }^{9}$

9 Pessoas com deficiência visual chegam a desistir de assistir a um filme se a voz do narrador da AD desagrada-lhes. Além disso, a narração é importantíssima para dar o tom correto aos diferentes gêneros cinematográficos. Podem um filme de terror e uma produção humorística serem narrados da mesma forma? E se houver uma partida de futebol que precise ser descrita bem no meio de um filme? Por que não fazê-lo como um locutor esportivo o faria? 
e o fato de que a $\mathrm{AD}$ é uma modalidade de tradução (portanto re-produção/ recriação do texto fonte);

d) A não inclusão de notas introdutórias em ADs pré-gravadas ou a sua omissão em produções ao vivo, bem como a omissão das visitas guiadas ao palco. ${ }^{10}$

Se o que se pretende com a AD, de fato, é tornar materiais acessíveis, fica evidente que o visocentrismo pouco colabora para o alcance desse objetivo, mas, ao contrário, prejudica a qualidade dos roteiros elaborados e traz consequências danosas como uma sobrecarga do processo cognitivo a ponto de, algumas vezes, impedir a fruição das obras audiodescritas.

O feedback especializado oferecido por um audiodescritor consultor é uma das maneiras de minimizar problemas como esse. No entanto, esse profissional precisa ser devidamente capacitado, por isso é de fundamental importância que seja discutida a questão de cursos de formação que preparem consultores para o exercício de sua função.

\section{A QUESTÃO DA FORMAÇÃO}

A tradução de imagens em palavras é um processo complexo que exige treinamento, experiência e uma série de competências. Diaz Cintas (2006), num documento intitulado Competencias profesionales del subtitulador y el audiodescriptor, discorre sobre as competências necessárias ao audiodescritor roteirista. Com base nesse texto, Silva (2016) realiza pesquisa e elenca as competências necessárias ao audiodescritor consultor. A autora cita, por exemplo, a necessidade de que o consultor tenha um conhecimento profundo do vernáculo (domínio do léxico e sintaxe da língua); habilidade de revisão e edição; domínio da teoria e prática da $\mathrm{AD}$; capacidade de produzir pensando não em si,

Isto não seria mais interessante para o público-alvo?

10 Notas introdutórias ou notas proêmias, geralmente usadas em apresentações ao vivo, consistem em um texto que antecede o espetáculo e no qual informações relevantes que não fazem parte da $\mathrm{AD}$ podem ser oferecidas (informações sobre segurança e serviços disponíveis, registro da presença de autoridades ou pessoas famosas, definição de termos pouco usuais presentes na obra, informações sobre o elenco, créditos e patrocinadores, uma sinopse etc.). As notas introdutórias muitas vezes são acompanhadas de visitas guiadas ao palco para que se possa tocar o cenário e figurinos, por exemplo. mas no universo do público-alvo; familiaridade com informática; e boa disposição para trabalhar em equipe e sob estresse e pressão. ${ }^{11}$

Silva (2016) faz questão de frisar que a lista de competências apresentada não se constitui numa lista de pré-requisitos para o exercício da profissão, mas num elemento norteador de propostas de qualificação de pessoas com deficiência visual para o trabalho com AD:

As entradas presentes em cada categoria são itens que podem ser usados para nortear a formação dos audiodescritores consultores e coletivamente constituem o objetivo final, o perfil ideal para a excelência desses profissionais; algo que só será alcançado no longo percurso de formação continuada que audiodescritores não videntes, assim como seus pares videntes, também têm de trilhar.

Os cursos de formação inicial são o primeiro passo nesse longo percurso de qualificação dos consultores. O momento atual, inclusive, é bastante propício para a discussão dessa questão. Com o reconhecimento da profissão e a aprovação de leis que tornam o recurso da $\mathrm{AD}$ obrigatório não só nos canais abertos de televisão, mas também no cinema, a pressão para que mais e mais bens culturais tornem-se acessíveis é cada vez maior. Como consequência, a demanda por cursos de formação em AD também é crescente.

Historicamente, o Brasil vinha utilizando dois modelos para formação em $\mathrm{AD}$ : treinamentos ministrados por audiodescritores com experiência de mercado ou cursos em nível de extensão universitária. Entretanto, nenhum dos modelos era considerado satisfatório. A carga horária reduzida não permitia um trabalho com a densidade e qualidade necessárias; o que levou, gradativamente, ao surgimento de cursos universitários em nível de especialização em AD. Atualmente, são oferecidos dois cursos: um pela Universidade Federal de Juiz de Fora (UFJF) na modalidade semipresencial e outro pela Universidade Estadual do Ceará (UECE) na modalidade a distância. Contudo, apesar do avanço com relação à carga horária, ouros problemas ainda persistem.

11 A lista completa com todas as competências elencadas por Silva (2016) encontra-se ao final deste artigo em forma de anexo. 
Os cursos de formação, especialmente os mais antigos, sempre tiveram como objetivo quase que exclusivo a formação de videntes, com o foco na capacitação de novos roteiristas. Em geral, quando os cursos de formação contam com a presença de pessoas cegas ou com baixa visão, o papel desses indivíduos é o de convidado. Eles dão seu testemunho pessoal quanto à deficiência visual e a sua experiência com a $\mathrm{AD}$, bem como opinam, enquanto usuários, sobre a qualidade das audiodescrições realizadas pelos alunos.

É verdade que a procura por qualificação em AD por parte de pessoas com deficiência visual é muito reduzida. No entanto, é preciso também reconhecer que, embora nunca tenha existido qualquer restrição à participação de pessoas cegas ou com baixa visão nos cursos de formação, também nunca houve muitos incentivos. Na maioria das vezes, os cursos não são desenhados tendo em mente a presença desse público e carecem de uma perspectiva inclusiva. Os materiais utilizados em sala de aula ou para atividades extraclasse, por exemplo, não estão em formato acessível, sequer contam com AD. Além disso, num contexto como o do Brasil em que nem mesmo o próprio recurso da AD é tão bem conhecido por seu público primário, é de se esperar que pouquíssimos desses indivíduos estejam conscientes da necessidade de profissionais com deficiência visual para atuar na área. Entretanto, a divulgação de cursos de capacitação, bem como da própria função de consultor em $\mathrm{AD}$ junto a centros de atendimento especializados, redes sociais e associações de cegos continua precária. Por fim, a prática equivocada do mercado audiovisual de conceder a qualquer pessoa cega ou com baixa visão o status de consultor em potencial, como se a deficiência visual em si mesma fosse suficiente para o exercício da função, também tem colaborado para a baixa procura por cursos de formação e a consequente escassez de consultores capacitados que vivemos na atualidade.

Essa realidade precisa mudar. Para que uma audiodescrição alcance seu objetivo é necessário que as necessidades e preferências de seu público-alvo sejam contempladas. Para tanto, três requisitos básicos precisam ser garantidos na fase de produção do roteiro de AD: a) É preciso que o audiodescritor vidente responsável pelo roteiro conheça sua audiência; b) É necessário que o audiodescritor consultor que dará feedback a esse roteirista seja um profissional capacitado; e c) É fundamental que esses dois profissionais saibam como trabalhar em parceria. Infelizmente, a maioria dos cursos de formação e treinamentos em AD oferecidos atualmente ainda não trabalha essas questões de modo satisfatório.

Para muitos dos futuros roteiristas, seu primeiro contato com a temática da deficiência visual se dá nos cursos de formação. Por isso, é comum nesses cursos a sugestão de que audiodescritores novatos usem vendas de olhos e assistam ao material a ser audiodescrito pela primeira vez apenas ouvindo os diálogos e efeitos sonoros. O intuito é que a supressão das imagens dê a essas pessoas uma noção mais clara dos desafios a serem enfrentados (personagens com vozes muito semelhantes, sons que poderiam ser interpretados como algo que não são, mudanças repentinas de ambiente etc.). A inclusão de módulos nos quais a temática da deficiência visual é discutida e a presença de convidados cegos e com baixa visão servem ao mesmo propósito, que é o de aproximar os futuros roteiristas de seu público-alvo.

No entanto, seria a adoção dessas estratégias suficiente para o alcance desse objetivo? O uso de vendas de olhos ou a supressão da imagem em materiais audiovisuais poderia simular a experiência do "não ver"? A mera presença de módulos sobre a deficiência visual seria capaz de eliminar ideias errôneas e pré-concebidas por parte dos futuros roteiristas quanto ao público primário da $\mathrm{AD}$ ? $\mathrm{O}$ feedback concedido pelos convidados durante as pouquíssimas visitas para análise dos exercícios de roteirização seria suficiente para assegurar que os roteiristas tivessem menos chances de criar sentenças dúbias, confusas ou ilógicas no futuro? Cremos que não.

O segundo passo a fim de garantir que as necessidades e preferências do público primário da AD sejam garantidas reside no feedback que só pode ser oferecido por audiodescritores consultores devidamente capacitados. Analisar um roteiro com base em critérios como gosto pessoal ou o próprio grau de deficiência visual em nada contribuirá para a qualidade final do produto audiodescrito. De pouca valia também serão os pedidos de mudança 
de construções lexicais ou sintáticas sem que os mesmos estejam acompanhados de explicações. Sem uma justificativa, os roteiristas perdem a oportunidade de aprender porque tais construções causam dificuldade e não há nenhuma garantia de que os mesmos problemas não venham a ocorrer no futuro. O domínio do vernáculo e a capacidade de edição por parte do consultor são importantes, já que também é seu papel contribuir para encontrar a forma mais precisa e sucinta de comunicar as informações consideradas indispensáveis. Por fim, solicitações que não levam em consideração as restrições técnicas da própria $\mathrm{AD}$ ou as limitações orçamentárias de cada projeto somente aumentarão o stress inerente ao processo e atrasarão a conclusão dos trabalhos cujos prazos são sempre exíguos.

Analisando a complexidade da tarefa e o nível técnico exigidos de um bom consultor, nos perguntamos: Qualquer pessoa com deficiência visual estaria apta a participar de um curso de formação em AD? Alguém cuja vivência com produtos audiovisuais/visuais fosse muito limitada e que possuísse proficiência linguística reduzida, por exemplo, seria um bom consultor em potencial? Por fim, com a participação tão pequena de pessoas com deficiência visual nos cursos de formação, o número de consultores sendo formados seria capaz de suprir a demanda crescente de AD que temos hoje? Novamente cremos que não.

Como visto até aqui, a existência de bons roteiristas e consultores é condição sine qua non para a garantia da qualidade de uma AD. Entretanto, um último critério ainda precisa ser assegurado para que esse objetivo seja alcançado: esses profissionais precisam saber como trabalhar em parceria. E isto independe do modelo adotado por cada prestador de serviço, ou seja, quer o consultor atue como revisor de roteiros elaborados previamente ou desenvolva os textos juntamente com os roteiristas. $\mathrm{A} \mathrm{AD}$, como as demais modalidades de tradução audiovisual, demanda bastante trabalho em equipe num contexto de intensa pressão devido a prazos extremamente curtos. Não há espaço para mal-estar por parte de roteiristas que se sintam constrangidos ao trabalhar com pessoas com deficiência visual por terem pouca familiaridade com esse público, nem para consultores que careçam de habilidades de relacionamento interpessoal e flexibilidade.
No entanto, o modelo de formação adotado até aqui tem contribuído para essa sinergia? Futuros roteiristas e consultores teriam como aprender a trabalhar em parceria sem exercícios práticos nesse sentido? A frequência de oportunidades para o trabalho colaborativo seria a ideal se a participação de pessoas com deficiência visual continuasse restrita apenas ao papel de convidado? A execução de exercícios de roteirização que não simulem as restrições e dificuldades mais comuns à atividade da AD prepararia os futuros profissionais para responder às demandas do mercado? Também cremos que não.

A preferência dos audiodescritores brasileiros pela consultoria realizada após a finalização do roteiro em detrimento da participação dos consultores na própria construção do texto parece endossar nossa crença de que os cursos de formação não têm trabalhado de modo efetivo a prática do trabalho colaborativo. Afinal, a construção conjunta de um roteiro demanda muito mais em termos de habilidades interpessoais e de trabalho em equipe com alguém que tenha capacidade visual diferente da sua. E, para tanto, é preciso de prática. Para ilustrar esse ponto, trazemos trechos do depoimento de uma roteirista ao descrever sua primeira experiência de trabalho construindo um roteiro em conjunto com um consultor: a) "No primeiro dia, gastamos muito tempo para audiodescrever menos da metade do filme [...]"; b) "O ponto negativo, conforme já destaquei, seria a sobrecarga para o audiodescritor (vidente) e a lentidão no processo de tradução [...]"; c) "A experiência foi válida, mas demonstrou-se improdutiva para a dinâmica que o mercado exige, bem como extremamente cansativa [...]". ${ }^{12}$

Como a roteirista em questão era uma profissional capacitada e o trabalho foi executado em conjunto com uma consultora também certificada, é de se supor que as dificuldades encontradas não poderiam ser justificadas pela falta de um curso de formação por parte de nenhuma das duas. Os contratempos enfrentados poderiam estar ligados, então, a lacunas nessa formação ou problemas de natureza interpessoal, pois há casos nos quais dois

12 Depoimento colhido como parte de pesquisa apresentada em comunicação intitulada Audiodescrição e formação profissional: fomentando uma parceria efetiva entre roteiristas e consultores no XII Seminário de Linguística Aplicada e VIII Seminário de Tradução realizado na Universidade Federal da Bahia em 2014. 
profissionais, por mais bem treinados que sejam, não conseguem uma boa sinergia trabalhando juntos. No entanto, como a própria informante salientou que o primeiro dia de trabalho foi o mais difícil, a hipótese da lacuna na formação parece ganhar força. Apesar da lentidão do processo quando comparado com o trabalho solitário a que a roteirista já estava acostumada, a profissional atesta em seu depoimento que a construção do texto passou a ser mais fluida à medida que novos encontros aconteceram.

Aqui, é importante salientar que a utilização desse depoimento é meramente ilustrativa no sentido de argumentar em favor da necessidade didática da inclusão de exercícios de roteirização nos quais videntes e consultores trabalhem em equipe, pois essa é a situação que mais demandará colaboração entre as partes. De modo algum estamos advogando que a roteirização profissional deva ser necessariamente realizada em conjunto com pessoas com deficiência visual. Ao ingressar no mercado, cada equipe de audiodescritores terá sua própria dinâmica de trabalho. $\mathrm{O}$ importante é que a figura do consultor esteja presente, quer durante a própria roteirização, quer revisando roteiros escritos por videntes.

Diante da exposição realizada nesta seção é possível perceber alguns dos atuais percalços no que tange à formação tanto de roteiristas quanto de consultores no Brasil. Entretanto, se focarmos na capacitação de pessoas com deficiência visual para o trabalho na área da $\mathrm{AD}$, que sugestões teríamos? De que modo poderíamos trabalhar para tentar garantir uma formação mais sólida e um perfil profissional mais coerente com as exigências do mercado?

\section{FORMANDO CONSULTORES}

O surgimento da AD no Brasil abriu possibilidades de trabalho para uma camada da população historicamente marginalizada, isto é, os cidadãos brasileiros com deficiência visual. Entretanto, assim como roteiristas e narradores, consultores não devem ser contratados com base em nenhum tipo de assistencialismo e essa política de profissionalização deve começar desde o estágio inicial de capacitação para atuação na área.
Em geral, para participar de cursos de formação, são exigidos certos pré-requisitos dos videntes (domínio do vernáculo, habilidade no manejo de certos programas de computador, formação universitária etc.). Algumas vezes, os candidatos são até mesmo submetidos a testes de seleção na disputa por vagas. Somos favoráveis a essas práticas e acreditamos que os futuros consultores devam enfrentar o mesmo tipo de exigências. Resguardado o número de vagas para pessoas com deficiência exigido na legislação, até mesmo para que a presença de pessoas cegas ou com baixa visão seja assegurada nos cursos, e garantida a acessibilidade das avaliações, não há por que facilitar o processo de seleção para esse público. Devemos lembrar que a deficiência visual por si só não é critério suficiente para o exercício da consultoria. Assim como nem todo vidente pode ser roteirista, nem toda pessoa com deficiência visual pode ser consultor.

Advogamos em favor de cursos de especialização em $\mathrm{AD}$ em detrimento da formação de consultores em cursos de curta duração. Como o grau de complexidade da atividade é grande, cursos acelerados não irão produzir os resultados desejados. Além disso, também defendemos que os cursos sejam desenhados levando em consideração uma perspectiva inclusiva, ou seja, que se preconize a formação conjunta de todos os profissionais da AD (roteiristas, consultores e narradores) e que a acessibilidade esteja presente em todas as fases do processo desde a seleção até as próprias aulas e etapas finais de avaliação. Desse modo, a inclusão e a acessibilidade deixariam de ser meras abstrações relegadas a um futuro distante que só se atualizariam no exercício profissional desses audiodescritores para se tornar uma realidade vivida a cada aula.

Acreditamos que cursos de formação devam aliar teoria e prática, ou seja, é necessário que os futuros consultores sejam submetidos a atividades nas quais, de fato, possam experienciar a função que irão exercer. Essas atividades devem incluir tanto exercícios de roteirização conjunta quanto o feedback de roteiros elaborados apenas por videntes. É importante também que esses exercícios simulem as exigências e limitações impostas pelo mercado (orçamentos apertados, prazos curtíssimos 
etc.) e que os futuros roteiristas deem retorno em relação ao desempenho dos colegas com deficiência visual na execução das tarefas (domínio da teoria da $\mathrm{AD}$, clareza e utilidade das observações feitas etc.). A adoção de uma perspectiva inclusiva defendida anteriormente traria vantagens também quanto à carga horária destinada a exercícios práticos. Ao agregar videntes e pessoas com deficiência visual num mesmo curso, teríamos a possibilidade do exercício da $\mathrm{AD}$ ao vivo ${ }^{13}$ por parte dos próprios alunos. O feedback constante e imediato dessas ADs não só garantiria que os futuros consultores pudessem acompanhar melhor as próprias aulas, como lhes daria bastante experiência no exercício de sua própria função.

Por fim, reforçamos a necessidade de divulgação tanto de cursos de formação, quanto da própria existência e importância da função de consultor entre a população com deficiência visual. Assim como enfrentamos a necessidade de formação de público para espetáculos audiodescritos pela pouca familiaridade com o recurso, precisamos atrair mais pessoas cegas e com baixa visão para cursos de capacitação em AD. A adoção de cursos na modalidade a distância pode ser uma saída para o problema. A familiaridade com o universo da informática, necessária para a consecução de um curso como esse, não só auxiliaria o próprio

13 Citamos como exemplo o relato de uma experiência com $\mathrm{AD}$ sussurrada realizada na Universidade de Granada na Espanha. Um aluno do curso de Fisioterapia teve o suporte de voluntários que se sentavam ao seu lado e descreviam em sussurros as ilustrações presentes em slides e transparências, a linguagem corporal do docente, os elementos visuais da interação do professor com os demais alunos e até as reações emocionais dos colegas a imagens consideradas repulsivas (LINARES, 2007). exercício profissional da consultoria, como poderia, posteriormente, garantir que os poucos profissionais formados estivessem aptos a oferecer seus serviços também a distância, suprindo, mesmo que temporariamente, a carência de bons consultores que vivemos hoje.

\section{CONSIDERAÇÕES FINAIS}

Atualmente, para além da mera garantia de que produtos culturais sejam audiodescritos, é preciso que se lute para que as ADs oferecidas tenham qualidade. Para tanto, é necessário educar o mercado e, entre outras coisas, deixar clara a valiosa contribuição oferecida pela presença do audiodescritor consultor. Pedidos de orçamento que não incluem os honorários desse profissional, bem como a prática de se eleger qualquer pessoa cega ou com baixa visão à categoria de consultor precisam ser evitados. A capacitação é condição sine qua non para o exercício dessa função.

Nesse sentido, cursos de especialização que ofereçam formação conjunta para roteiristas, narradores e consultores, bem como atividades práticas com ênfase no trabalho colaborativo devem dar a tônica aos cursos de capacitação na área. Desse modo, não só teremos consultores que poderão desempenhar seu papel a contento, trabalhando em sinergia com os demais profissionais da $\mathrm{AD}$, como poderemos dar ainda maior destaque à função social dessa modalidade de tradução. Afinal, ao adotar cursos numa perspectiva inclusiva e fomentar uma parceria mais efetiva entre consultores, roteiristas e narradores estaremos provando que a inclusão e a acessibilidade podem e devem começar muito antes do consumo dos produtos audiodescritos.

\section{REFERÊNCIAS}

ASOCIACIÓN ESPAÑOLA DE NORMALIZACIÓN Y CERTIFICACIÓN. UNE 153020: Audiodescripción para personas con discapacidad visual. Requisitos para la audiodescripción y elaboración de audioguías. Madrid, 2005.

BITTNER, Hansjörg. Audio description guidelines: a comparison. New Perspectives in Translation, v. 20, p. 41-61, 2012. Disponível em: $<$ https://www.uni-hildesheim.de/media/_migrated/content_uploads/AD_Guidelines_Comparison_-_Read.pdf>. Acesso em: 10 mar. 2017.

CARNEIRO, Bárbara Cristina dos Santos. Repensando o roteiro de audiodescrição para o público com deficiência intelectual. 2015. 284f. Dissertação (Mestrado em Tradução Audiovisual e Acessibilidade) - Programa de Pós-Graduação em Língua e Cultura, Instituto de Letras, Universidade Federal da Bahia, Salvador, 2015.

DÍAZ CINTAS, Jorge. Competencias profesionales del subtitulador y del audiodescriptor. Madrid: CESyA, 
2006. Disponível em: <http://www.cesya.es/files/documentos/informe_formacion.pdf>. Acesso em: 24 set. 2013.

FELLOWES, Judith. Espectro autístico, legendas e áudio-descrição. Tradução de Tereza R. Gomes. Revista Brasileira de Tradução Visual (RBTV), v. 13, 2012. Disponível em: <http://www.associadosdainclusao.com. br/enades2016/sites/all/themes/berry/documentos/15-espectro-autistico-legendas-e-audio-descricao-por-judith-fellowes-traducao-de-tereza-r-gomes.pdf>. Acesso em: 02 jan. 2017.

LINARES, Irene M. Chuchotage para ciegos: un susurro ensayado. In: HURTADO, Catalina J. (Ed.). Traducción y accesibilidad - subtitulación para sordos y audiodescripción para ciegos: nuevas modalidades de Traducción Audiovisual. Alemanha: Peter Lang, 2007. p. 209-227.

MATTOSO, Verônica de Andrade. Ora, direis, ouvir imagens? Um olhar sobre o potencial informativo da áudio-descrição aplicada a obras de arte visuais bidimensionais como representação sonora da informação em arte para pessoas com deficiência visual. 2012. 187f. Dissertação (Mestrado em Ciência da Informação) - Programa de Pós-graduação em Ciência da Informação, Universidade Federal do Rio de Janeiro, Rio de Janeiro, 2012. Disponível em: <http://ridi.ibict.br/handle/123456789/764>. Acesso em: 20 jan. 2017.

O'SULLIVAN, Emer. Narratology meets translation studies, or the voice of the translator in children's literature. In: LATHEY, Gillian (Ed.). The translation of children's literature: a reader. Clevedon: Multilingual Matters Ltd., 2006a. p. 98-109.

. Translating pictures. In: LATHEY, Gillian (Ed.). The translation of children's literature: a reader. Clevedon: Multilingual Matters Ltd., 2006b. p. 113-121.

PACKER, Jaclyn. Psychosocial benefits of accessible television for blind/visually impaired persons. 1995. Paper presented at American Psychological Association national convention, New York City, 1995 apud PACKER, J. Video description in North America. In: BURGER, Dominique (Ed.). New technologies in the education of the visually handicapped. Paris: John Libbey Eurotext, 1996. p. 103-107.

RAI, Sonali; GREENING, Joan; PETRÉ, Leen. A comparative study of audio description guidelines prevalent in different countries. London: Media and Culture Department, Royal National Institute of Blind People (RNIB), 2010. Disponível em: <http://audiodescription.co.uk/uploads/general/RNIB._AD_standards1.pdf $>$. Acesso em: 26 jul. 2017.

RIBEIRO, Ernani N.; LIMA, Francisco José de. Contribuições da áudio-descrição para a aprendizagem de educandos surdos. Revista Brasileira de Tradução Visual (RBTV), v. 10, 2012.

SCHMEIDLER, Emilie; KIRCHNER, Corinne. Adding audio description: does it make a difference? Journal of Visual Impairment \& Blindness, New York, v. 95, n. 4, p. 197-212, Apr. 2001.

SILVA, Manoela Cristina C. C. da. Audiodescritor consultor: competências necessárias ao profissional não vidente. In: ADERALDO, Marisa Ferreira. Et al (Org.). Pesquisas teóricas e aplicadas em audiodescrição. Natal: EDUFRN, 2016. Disponível em: <https://repositorio.ufrn.br/jspui/handle/123456789/22612>. Acesso em: 26 jul. 2017.

SNYDER, Joel. Audio description - the visual made verbal. In: DÍAZ CINTAS, Jorge (Ed.). The didactics of audiovisual translation. Amsterdam/Philadelphia: John Benjamins Publishing Company, 2008. p. 191-198.

VERCAUTEREN, Gert. A narratological approach to content selection in audio description. Towards a strategy for the description of narratological time. Monografias de Traducción e Interpratación (MonTi), n. 4, p. 207-231, 2012. Disponível em: <http://www.e-revistes.uji.es/index.php/monti/article/view/1594>. Acesso em: 11 fev. 2017.

Recebido: $29 / 07 / 2017$

Aprovado: 11/10/2017 


\section{ANEXO}

\section{COMPETÊNCIAS NECESSÁRIAS AO AUDIODESCRITOR CONSULTOR}

\section{COMPETÊNCIAS LINGUÍSTICAS}

a) Conhecimento profundo do idioma (domínio do léxico e sintaxe da língua);

b) Criatividade e sensibilidade linguísticas (saber expressar-se bem oralmente e por escrito, capacidade de fazer boas escolhas linguísticas);

c) Competência para revisão e edição (capacidade de se expressar de modo preciso e sucinto, capacidade de selecionar informações visuais indispensáveis).

\section{COMPETÊNCIAS TEMÁTICAS OU DE CONTEÚDO}

a) Conhecimento profundo do universo da deficiência visual e das necessidades e preferências do público-alvo em relação à $\mathrm{AD}$ (troca de experiências com pessoas com deficiência visual maior ou menor que a sua, capacidade de produzir pensando não em si, mas no universo do público-alvo);

b) Conhecimento da área na qual produzirá $\mathrm{AD}$ (conhecimento da linguagem cinematográfica, teatral etc.);

c) Conhecimento profundo da teoria e prática da $\mathrm{AD}$ (formação em $\mathrm{AD}$ );

d) Competência para lidar com questões de produção (preocupação com um espaço acessível, produção de material em braile e fonte ampliada);

e) Competência para captação de recursos (conhecimento da legislação, capacidade de elaboração de projetos culturais e de inscrição em editais).

\section{COMPETÊNCIAS TECNOLÓGICAS E APLICADAS}

a) Familiaridade com o universo da informática (manejo de computadores, uso da internet);

b) Domínio do aparato tecnológico para roteirização (conhecimento de programas necessários para elaboração da $\mathrm{AD}$; de diferentes formatos de arquivos; do transporte, armazenamento e intercâmbio de dados);

c) Conhecimentos de locução;

d) Conhecimentos de gravação e edição de áudio;

e) Domínio de estratégias de documentação.

\section{COMPETÊNCIAS PESSOAIS E GERAIS}

a) Amplo repertório cultural;

b) Boa disposição para trabalhar em equipe (espírito de grupo, habilidade de relacionamento interpessoal, flexibilidade);

c) Capacidade de aprendizagem autônoma (autonomia, gosto pelo estudo, sede de novos conhecimentos e vivências, busca constante de atualização);

d) Capacidade de análise e interpretação de informações (capacidade de observação, objetividade, poder de síntese);

e) Capacidade de trabalhar em condições de estresse e pressão (organização, agilidade, rapidez, disponibilidade, disposição);

f) Postura profissional e ética. 